\title{
Terhesség és szülés trophectoderma-biopsziát követően vitrifikált blasztociszták beültetésével
}

\author{
Mátyás Szabolcs dr. ${ }^{1}$ - Varga Tünde ${ }^{2}$ - Kovács Péter dr. ${ }^{1}$ \\ Kónya Márton ${ }^{2}$ - Rajczy Klára ${ }^{1}$ - Babenko Éva ${ }^{1}$. Szabó Barbara ${ }^{1}$ \\ Kaali G. Steven dr. ${ }^{1}$ - Szentirmay Zoltán dr. ${ }^{2}$ \\ ${ }^{1}$ Kaáli Intézet, Budapest \\ ${ }^{2}$ Istenhegyi Géndiagnosztikai, Nőgyógyászati és Családtervezési Centrum, Budapest
}

\begin{abstract}
A preimplantációs genetikai diagnózis alkalmazásával lehetőség van arra, hogy beültetésre csak egy adott genetikai rendellenességben nem érintett preembriók kerüljenek. A szerzők trophectoderma-biopszia és vitrifikáció kombinációját alkalmazták monogénes betegség vizsgálatára. A genetikai vizsgálat indikációja a feleség korábban diagnosztizált l-es típusú neurofibromatosisa volt. Az in vitro fertilizáció és a preembriók tenyésztése szekvenciális tápoldatok alkalmazásával történt. Az ötödik napon hét blasztocisztából lehetett mintát venni, amelyeket ezután vitrifikáltak. A polimeráz láncreakcióval végzett genetikai vizsgálat eredménye alapján két blasztociszta rendelkezett normális genotípussal. A felengedett blasztociszták beültetését és zavartalan terhességet követően az asszony egészséges fiúgyermeknek adott életet. Orv. Hetil., 2015, 156(44), 1787-1792.
\end{abstract}

Kulcsszavak: preimplantációs genetikai diagnosztika, in vitro fertilizáció, embriótranszfer, polimeráz láncreakció, vitrifikáció

\section{Pregnancy and delivery with transfer of vitrified blastocysts following trophectoderm biopsy}

\begin{abstract}
Application of preimplantation genetic diagnosis makes it possible to transfer only embryos unaffected by a certain genetic disorder. The authors have applied the combination of trophectoderm biopsy and vitrification in order to detect a monogenic disorder. Previously diagnosed type 1 neurofibromatosis of the woman was the indication for genetic examination. In vitro fertilisation and embryo culture was performed using sequential culture mediums. Seven blastocysts could be sampled on the fifth day and were vitrified subsequently. Two blastocysts turned out to be genetically normal based on the result of genetic examination using polimerase chain reaction. A healthy boy was delivered following the transfer of warmed blastocysts and an uneventful singleton pregnancy.
\end{abstract}

Keywords: preimplantation genetic diagnosis, in vitro fertilization, polymerase chain reaction, vitrification

Mátyás, Sz., Varga, T., Kovács, P., Kónya, M., Rajczy, K., Babenko, É., Szabó, B., Kaali, G. S., Szentirmay, Z. [Pregnancy and delivery with transfer of vitrified blastocysts following trophectoderm biopsy]. Orv. Hetil., 2015, 156(44), 1787-1792.

(Beérkezett: 2015. július 16.; elfogadva: 2015. szeptember 1.)

\section{Rövidítések}

aCGH = arrayalapú komparatív genomiális hibridizáció; AMH $=$ anti-Müllerian-hormon; ET $=$ embriótranszfer; FET $=\mathrm{fa}-$ gyasztott-felengedett embrió transzfer; FISH = fluoreszcens in situ hibridizáció; FSH = folliculusstimuláló hormon; GnRHa = gonadotropin releasing hormon agonista; HRM = nagy felbontású olvadáspont-analízis; IVF = in vitro fertilizáció; $\mathrm{LH}=$ luteinizáló hormon; NFl = neurofibromin-l gén; NGS = új generációs szekvenálás; OPS = open pulled straw; $\mathrm{PBS}=$ foszfátpufferoldat; $\mathrm{PCR}=$ polimeráz láncreakció; $\mathrm{PGD}=$ preimp- 
lantációs genetikai diagnózis; PGS = preimplantációs genetikai szűrés; SNP = egypontos nukleotid-polimorfizmus; STR $=$ rövid tandem ismétlődések; Tm = olvadáspont; UP-HRM = jelöletlen próbás nagy felbontású olvadáspont-analízis; VIT = vitrifikált-felengedett embrió transzfer

Genetikai rendellenességet hordozó párok gyermekvállalása komoly kockázattal jár. A terhesség gyakran spontán vetéléssel ér véget, másrészt a megszületett gyermekek öröklött betegségével, esetleg korai halálával is számolni kell. Az egészségügyi kockázaton kívül ez szociális terhet is jelent a szülók és a társadalom számára, illetve komoly etikai kérdéseket vet fel. A magzati korban végzett praenatalis genetikai vizsgálat eredményének ismeretében már csak a létrejött terhesség esetleges megszakítására van lehetőség.

Preimplantációs genetikai diagnózis (PGD) klinikai alkalmazásáról először 1990-ben számoltak be [1], azóta egyre szélesebb körben alkalmazzák [2,3]. A PGD célja az, hogy beültetésre csak az adott genetikai rendellenességben nem érintett embriók kerüljenek. Hagyományosan a genetikai vizsgálat monogénes betegségek esetén polimeráz láncreakcó (PCR), számbeli és szerkezeti kromoszóma-rendellenességek esetén pedig fluoreszcens in situ hibridizáció (FISH) alkalmazásával történik. Nemhez kapcsolt örökletes betegségek esetén mindkét módszert alkalmazzák $[4,5]$. Az utóbbi években újabb vizsgálati módszerek - arrayalapú komparatív genomiális hibridizáció (aCGH), egypontos nukleotid-polimorfizmus (SNP), új generációs szekvenálás (NGS) - is bevezetésre kerültek [6]. A mintavétel során a zona pellucidát mechanikusan (parciális zónadissectio - PZD), savas Tyrode-oldattal vagy lézerrel megnyitják. Harmadik napon az 5-10 sejtes preembrióból egy vagy két blasztomert vesznek ki mikromanipulátor segítségével [7]. Ehhez a preembriót először kalcium- és magnéziummentes tápoldatba helyezik a sejtek közötti szoros kapcsolatok oldására [8]. Alternatív lehetôségként a petesejt első, illetve második sarki testéből is elvégezhető a vizsgálat, viszont ebben az esetben csak a petesejtről kapunk információt [9]. Lehetőség nyílik továbbá a megtermékenyítést követő ötödik napon, blasztociszta stádiumban, trophectoderm sejtek biopsziájára [10]. Trophectoderma-biopszia esetén a genetikai vizsgálat elvégzésére rendelkezésre álló idő lényegesen rövidebb a sarkitest-, illetve blasztomerbiopsziához képest, mivel a beültetést optimális esetben a mintavétel napján kellene elvégezni. A korlátozott időre megoldást jelent a blasztociszták mélyhűtése a biopsziát követően. Hagyományos lassú fagyasztás esetén a felengedést követően végzett embrióbeültetések (fagyasztott-felengedett embrió transzfer FET) relatíve alacsony hatékonysága miatt az ötödik napi mintavétel az utóbbi évekig kompromisszumos megoldást jelentett. Korszerú vitrifikációs technika alkalmazásával ezt a problémát is sikerült megoldani [11]. Így végül lehetővé vált trophectoderma-biopszia rutin- szerú alkalmazása olyan esetekben is, amikor a hosszabb vizsgálati idő miatt nincs lehetőség az embriók beültetésére ugyanabban a ciklusban. Esetismertetésünkben sikeres PGD-ciklusunkat ismertetjük, amelynek során az ötödik napon végzett trophectoderma-biopszia után a blasztocisztákat vitrifikáltuk. A genetikai vizsgálat eredményének birtokában a vitrifikált blasztociszták felengedése és beültetése (VIT) későbbi ciklusban történt.

\section{Módszer}

A 34 éves asszony anamnézisében l-es típusú neurofibromatosis szerepelt, amelyet az NFl génjének de novo defektusa okozott (heterozigóta c.1870delT mutáció, NM_000267.3). A betegség autoszomális domináns módon öröklődik. Korábban másfél éven belül három esetben múvi terhességmegszakításra került sor a magzat érintettsége miatt. Az előzetes kivizsgálások során az alaphormonértékek a következők voltak: FSH 6,4 mIU/ $\mathrm{mL}, \mathrm{LH} 4,3 \mathrm{mIU} / \mathrm{mL}$, AMH 1,5 ng/L. A férj spermavizsgálata normozoospermiát mutatott: 70 millió $/ \mathrm{mL}$ koncentráció, $50 \%$ motilitás, $57 \%$ normálmorfológia. GnRH-antagonista és rekombináns FSH alkalmazásával kivitelezett hormonális stimulációt követően 2013. május 16-án transzvaginális ultrahang-vezérlésű folliculusaspiráció során 11 petesejtet nyertünk. A petesejteket a megtermékenyítésig SAGE PP Fertilization oldatban tenyésztettük. Három órával a petesejtnyerés után az elözetesen megtisztított (Hyase, SAGE) 11 érett (MII) petesejtet intracitoplazmatikus spermiuminjekció alkalmazásával termékenyítettük meg. A petesejtek és a preembriók tenyésztéséhez a megtermékenyítést követően SAGE PP Cleavage Stage, majd harmadik naptól PP Blastocyst Stage tápoldatokat használtunk. Az inkubációt redukált oxigénkoncentráció $(5 \%)$ mellett, Planer BT 37 asztali inkubátorban végeztük. 18 órával a megtermékenyítés után 10 petesejtben két előmagot (pronucleus), 1 petesejtben pedig egy előmagot lehetett megfigyelni. Negyedik napon a 11 osztódó preembrió zona pellucidáját lézer (Octax, MTG) segítségével megnyitottuk. Ötödik nap reggel négy korai blasztociszta és három kompakt morula stádiumú preembriót lehetett megfigyelni. Négy preembrió fejlődése megállt a korai osztódások szakaszában. A három kompakt morula néhány órával késóbb érte el a korai blasztociszta stádiumot. A trophectoderm sejtek egy része kitüremkedett a zona pellucidán kialakított apró nyíláson. A blasztocisztákat paraffinolajjal (Ovoil, Vitrolife) fedett mikrocseppben (GMOPS Plus, Vitrolife) mikropipetta (MPH, Humagen) segítségével rögzítettük, majd speciális biopsziás mikropipettával megragadtuk a kitüremkedő trophectoderm sejteket. A trophectoderm sejtek közötti kapcsolatot lézerrel és mechanikusan oldottuk (1-4. ábra). A mintát ezután PBS-oldatban mostuk, majd 0,5-1,0 $\mu \mathrm{l}$ PBS-oldattal PCR-csőbe helyeztük. Ezt követően 2,5 $\mu \mathrm{l}$ lizálóoldatot mértünk a minta tetejére. A mintavétel után a blasztocisztákat egyesével, egyedi számozással, 


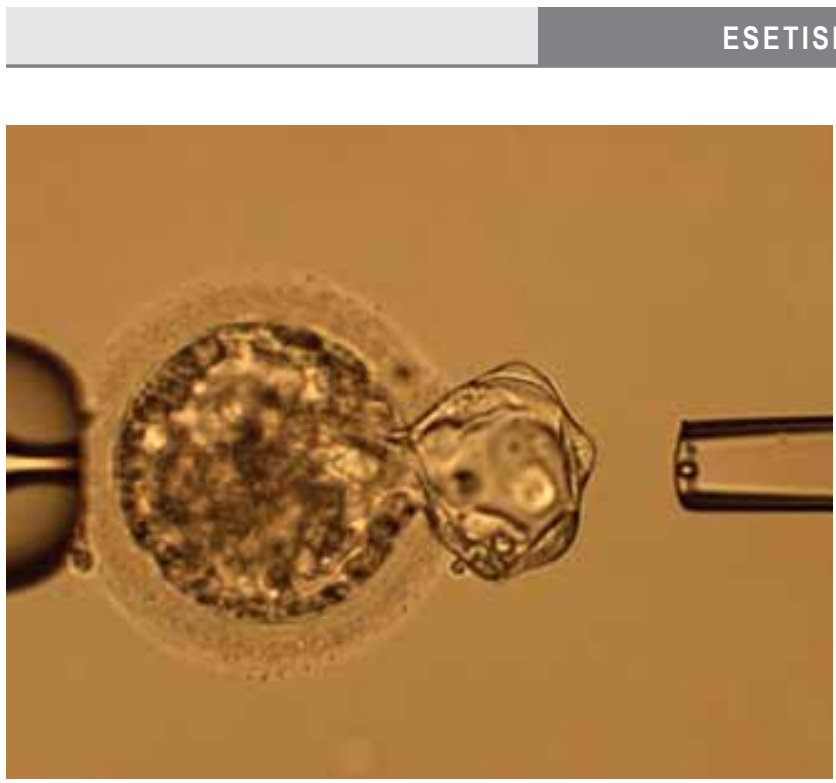

1. ábra

| Zona pellucida nyílásán kitüremkedő trophectoderma sejtek

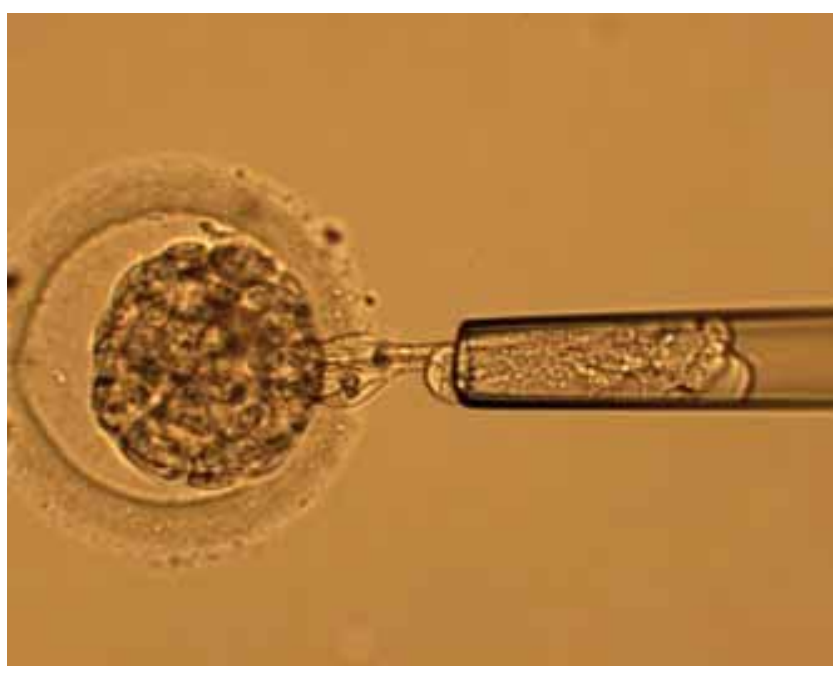

3. ábra

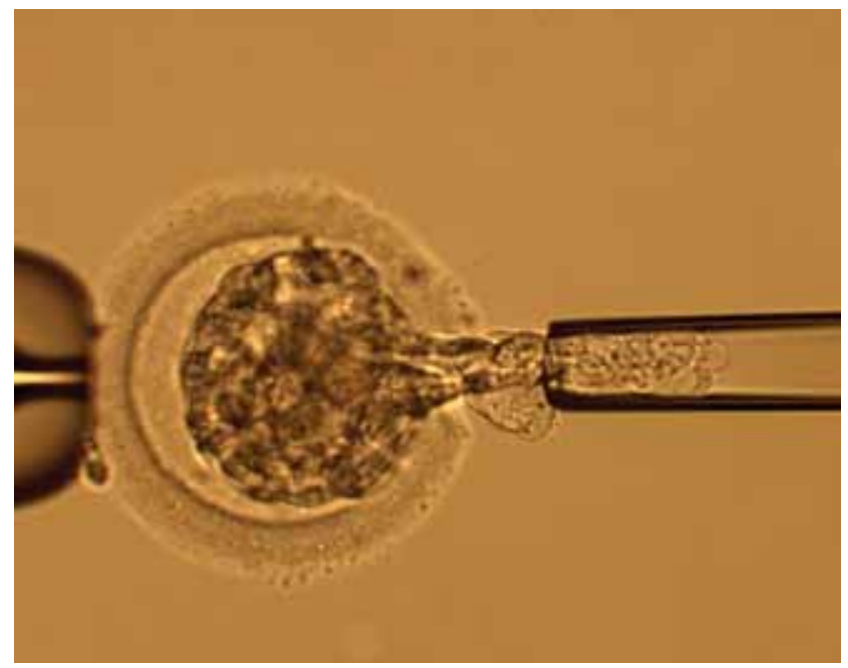

2. ábra | Trophectoderma sejtek megragadása mikropipettával

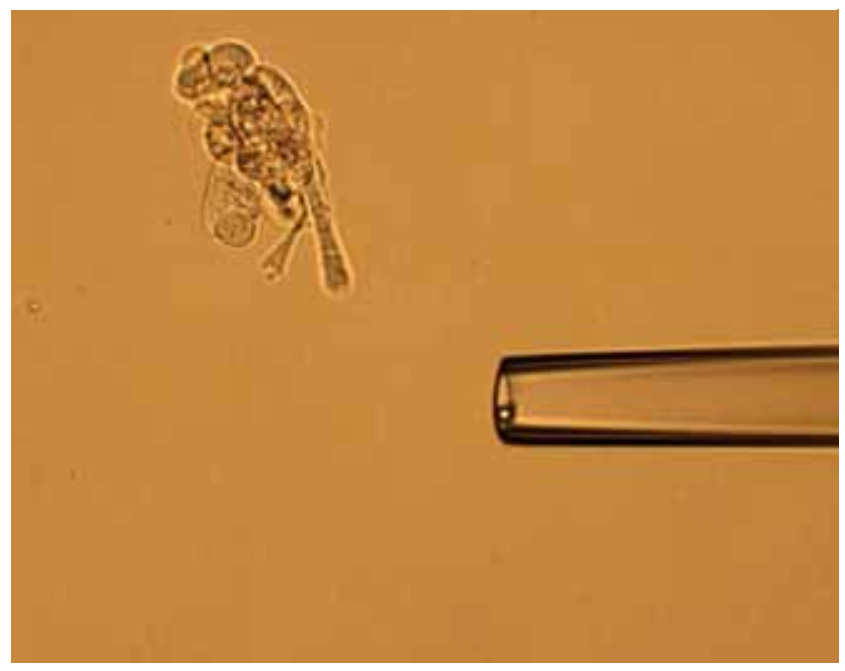

4. ábra | Eltávolított trophectoderma sejtek

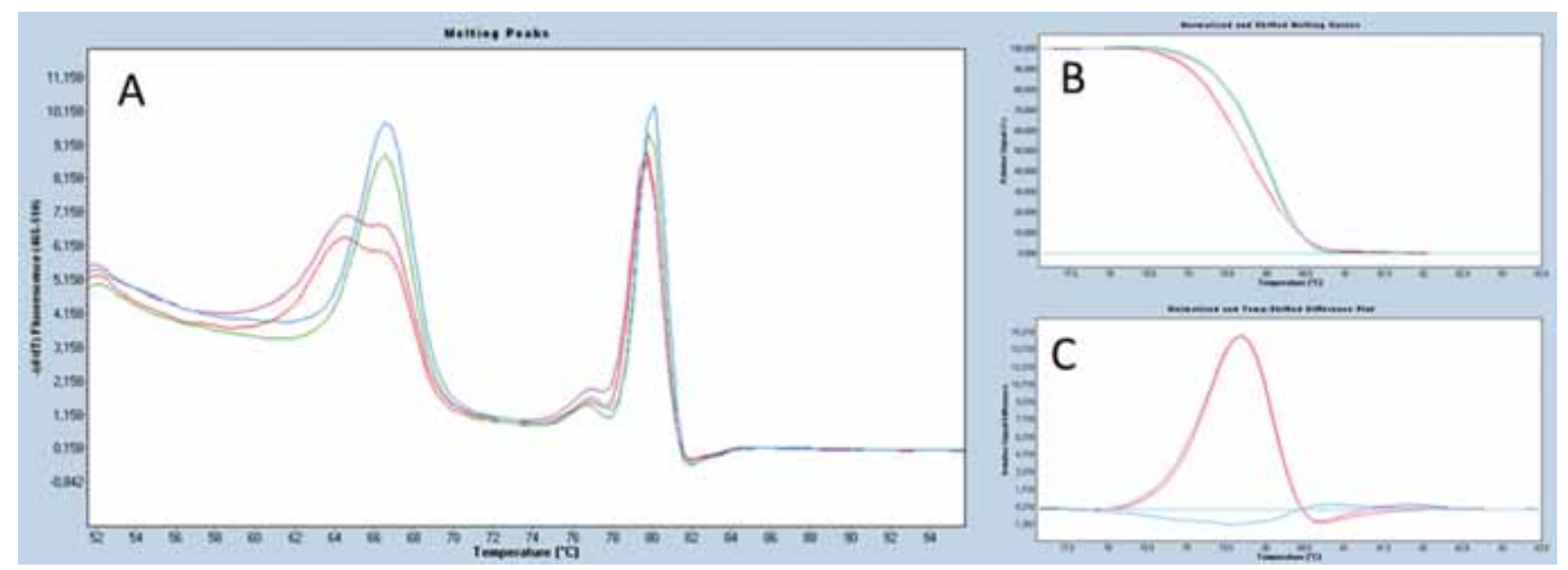

5. ábra $\quad$ Az anyai NFl-génmutáció detektálása UP-HRM módszerrel 
külön-külön mikrocseppben (SAGE PP Blastocyst) inkubáltuk a vitrifikáció előtt. A vitrifikációhoz Fertipro VitriFreeze oldatokat és OPS (open pulled straw, RVT) múszalmát használtunk.

Az embriókból kiemelt sejteket egyedileg jelölt PCRcsövekben szállítottuk át a molekuláris genetikai laboratóriumba, ahol genotipizálásuk történt. A vizsgálathoz az esetre előzetesen kidolgozott kimutatási módszert alkalmaztunk, amellyel egyidejüleg két markert - a patogén mutációt és egy kapcsolt, intragenikus STR-markert - vizsgáltunk. A módszerrel a betegséget okozó NFl génmutáció direkt vizsgálata mellett indirekt módon is követhető volt a hibás NFl gén öröklődése. A trophectoderm sejteket alkalikus lízissel tártuk fel, amely során 15 percig inkubáltuk őket 65 Celsius-fokon, a mintavételkor rájuk helyezett 2,5 $\mathrm{ul}$ lízispufferben $(50 \mathrm{mM}$ dithiothreitol, $200 \mathrm{mM} \mathrm{KOH}$ ). A lízispuffert a sejtek feltárását követően 2,5 $\mu$ l neutralizáló pufferrel semlegesítettük (900 mM Tris_HCl, $300 \mathrm{mM} \mathrm{KCl,} 200 \mathrm{mM}$ $\mathrm{HCl}$ ). A mintákra ezt követően mértük rá a multiplex PCR master mixet, amely tartalmazta a mutációt hordozó génszakasz és a kapcsolt marker kimutatására alkalmas primerpárokat. A multiplex PCR-reakciók $50 \mu$ l végtérfogatban zajlottak, 0,2 $\mu \mathrm{M}$ primer végkoncentrációkkal, Qiagen Type-IT microsatellite PCR-kittel (PCR-program: $95^{\circ} \mathrm{C} 5 \mathrm{~min} ; 45$ ciklus $95^{\circ} \mathrm{C} 30 \mathrm{~s}, 56{ }^{\circ} \mathrm{C} 90 \mathrm{~s}, 72{ }^{\circ} \mathrm{C}$ $\left.30 \mathrm{~s} ; 68{ }^{\circ} \mathrm{C} 10 \mathrm{~min} ; 4{ }^{\circ} \mathrm{C} \infty\right)$. A multiplex reakciók sikerességét (várt PCR-fragmentek jelenlétét) kapilláris gélelektroforézissel ellenőriztük Agilent microchipen (Agilent 2100 bioanalyzer, DNA 1000 Kit). A multiplex reakciók termékeit egy tisztítási lépés után (Agencourt AMPure XP magnetic beads) singlepex reakciókban vizsgáltuk tovább. A patogén NFl-mutációt hordozó génszakasz vizsgálata UP-HRM módszerrel történt, a mutációt fedő próba olvadása alapján. Az NFl-mutációt detektáló PCR-reakciókban aszimmetrikus primer koncentrációkat $(0,06-0,6 \mu \mathrm{M})$ használtunk, a detektálást szaturáló LC Green DNS-festékkel, 0,2 $\mu \mathrm{M}$ jelöletlen próbával végeztük, Roche LC480 real-time PCR-készüléken (5. ábra). Az 5. ábrán egy vad típusú és egy mutációt hordozó embrió analízise látható vad és mutáns kontrollok mellett. Kék görbe: normálkontroll, rózsaszín görbe: heterozigóta mutáns kontroll, zöld görbe: egészséges embrió, piros görbe: heterozigóta mutáns embrió. $\mathrm{Az} A$ ) ábra: a reakciómixek Tm-analízise. Az alsóbb hőmérsékleti tartományban $\left(60-70{ }^{\circ} \mathrm{C}\right)$ a mutációt fedő próba, a felsóbb hőmérsékleti tartományban (74-84 $\left.{ }^{\circ} \mathrm{C}\right)$ a teljes amplikon olvadási csúcsai láthatók. A próba vad allél esetében $66^{\circ} \mathrm{C}$-on, mutáns (delT) allél esetében $64^{\circ} \mathrm{C}$-on olvad. A homozigóta vad minták esetében (kék és zöld színnel jelölve) a próba csak $66^{\circ} \mathrm{C}$-on ad jelet, a heterozigóta mutáns minták esetében (rózsaszínnel és pirossal jelölve) a próba 64 és $66^{\circ} \mathrm{C}$-on, két csúccsal olvad. A módszer HRM-analízissel történő értékelést is lehetővé tesz, amely során az $A$ ) ábra felső hömérsékleti tartományában látható amplikon csúcsok elemzése történik meg. A B) ábrán a normalizált olva- dásgörbék, míg a $C$ ) ábrán a normalizált olvadásgörbék differenciált plot analízise látható. A vad típusú minták olvadásgörbéi mindkét analízis során egyértelmúen elkülönülnek a mutációt hordozó mintáktól.

A multiplex reakció másik termékét, a kapcsolt intragenikus STR-markert (D17S2163) fluoreszcens fragmenthossz-analízissel vizsgáltuk tovább. Az embrióknál a szülői fragmenthosszak kombinációi összhangban voltak a direktmutáció-kimutatás eredményével, kontaminációra utaló fragmenthossz a mintákban nem volt kimutatható.

\section{Eredmények}

A vizsgálat során öt embrióra vonatkozóan tudtunk genetikai eredményt adni, amelyből három hordozta az anyai mutációt, kettő pedig normális genotípusú volt. A két normális genotípussal rendelkező blasztociszta felengedésére 2013. június 16-án került sor. A felengedéshez Fertipro VitriThaw oldatokat használtunk. A felengedést követően a két blasztocisztát három órán keresztül inkubáltuk. A beültetéshez Wallace-katétert használtunk. Az embriótranszfer után az asszonyt szülész-nőgyógyászához irányítottuk. Zavartalan terhességet követően az asszony egészséges fiúgyermeknek adott életet.

\section{Megbeszélés}

PGD klinikai alkalmazásáról először 1990-ben számoltak be $[1,12]$. A PGD-eljárást nemcsak meddő, hanem olyan nemzőképes párok is igénybe vehetik, akiknél ismert genetikai rendellenesség miatt van szükség az in vitro fertilizációs beavatkozás során elvégzett genetikai vizsgálatra. A módszer alkalmazásával magasabb implantációs rátát értek el, és a spontán vetélések előfordulása is ritkább volt $[13,14]$. A 2000-ben Bolognában megrendezett kongresszus (3rd International Symposium on Preimplantation Genetics) időpontjáig már több mint 2500 ciklust végeztek el a világon, amelynek eredményeként közel 500 gyermek született meg. A PGD-t követően megszületett első 236 gyermek között 11 malformáció fordult elő $(4,7 \%)$, ami hasonló az átlagpopulációnál megfigyelt gyakorisághoz $[15,16]$.

$\mathrm{Az}$ eredményesség szempontjából fontos, hogy elegendő számú és minőségű preembrió álljon rendelkezésre a mintavétel időpontjában. Harmadik napi biopszia esetén a korlátozott mintaszám (egy vagy két blasztomer) is befolyásolja a hatékonyságot. A probléma kiküszöbölésére több lehetőség kínálkozott. A mintaszám növelésére egyrészt a blasztociszta stádiumban végzett trophectoderma-biopszia kínálkozott alternatívaként, másrészt felmerült a harmadik napon eltávolított blasztomerek in vitro replikációja is [17]. A rutin klinikai gyakorlatban a trophectoderma-biopszia terjedt el. Ehhez azonban szükség volt rövidebb vizsgálati módszerek, illetve hatékonyabb krioprezervációs technika kifejlesztésére. 
A számfeletti, visszaültetésre nem kerülő preembriók mélyhütése (lassú fagyasztás vagy vitrifikáció) mindennapos gyakorlat az in vitro fertilizációval (IVF) foglalkozó intézetekben. Az első mélyfagyasztott humán preembrió visszaültetése után létrejött terhességról 1983-ban [18], az első megszületett gyermekről pedig 1985-ben számoltak be [19]. Hosszú ideig a lassú fagyasztás volt az egyetlen széles körben alkalmazott technika az IVFcentrumokban. Vitrifikációt először rágcsálók embrióinak mélyhütésénél alkalmaztak [20]. Ennél a módszernél a nagy hütési sebesség miatt nem alakulnak ki jégkristályok sem az intracelluláris, sem pedig az extracelluláris térben. Az oldat üvegszerú állapotban dermed meg, innen ered a neve is. Ennek a folyamatnak az elősegítésére nagy viszkozitású vitrifikációs oldatot használnak. Emellett a gyors hütés (>-10 $000{ }^{\circ} \mathrm{C} /$ perc) is elengedhetetlen ahhoz, hogy a jégkristályok képződését elkerüljék. Ezt egyelőre csak kisebb térfogatú mintáknál $(0,5-2 \mu \mathrm{L})$ sikerült megoldani. A kis térfogat eléréséhez különféle müanyag hordozót használnak. Az első hatékony vitrifikációs módszernél a kis térfogatot egy nyitott, elvékonyított múszalma (open pulled straw - OPS) biztosította, amelybe a mintát a kapilláris erő segítségével szívták fel [21]. Később az OPS mintájára más múanyag hordozók is bevezetésre kerültek, így Cryotop vitrifikációnál müanyag lapocskát [22], Cryoloop vitrifikációnál pedig műanyag hurkot [23] használnak. Krioprotektánsként fóleg etilén-glikolt (EG) használnak, amit a toxicitás kiküszöbölése érdekében más krioprotektánssal - dimetil-szulfoxid (DMSO), propilén-glikol (PG), acetamid, Ficoll, szacharóz - kombinálnak [24]. Bármelyik vitrifikációs technika helyes alkalmazása gyakorlást igényel. Saját tapasztalataink alapján az OPS-módszer viszonylag könnyen elsajátítható a többi módszerhez képest. Korszerű vitrifikációs technikák alkalmazásával a lassú fagyasztásnál magasabb túlélési és implantációs rátát lehet elérni az embrionális fejlődés bármely stádiumában és a petesejteknél is $[25,26,27,28]$. A vitrifikáció térhódítása révén ma már a trophectoderma-biopszia is rutinszerüen alkalmazott technikát jelent a blasztomerbiopszia mellett.

Egy két éve publikált cikk eredményei azt mutatják, hogy az ötödik napi biopszia az implantációs ráta szempontjából is előnyösebb a harmadik napi biopsziához képest [29]. A vizsgálat során minden esetben két embriót ültettek vissza, amelyek közül az egyikből a harmadik vagy ötödik napon mintát vettek. A mintákból arrayalapú SNP-vizsgálatot végeztek. A megszületett gyermekek SNP-profilja alapján így utólag nyomon lehetett követni, hogy a két beültetett embrió közül melyik implantálódott. A harmadik napi mintavételt követően $20 \%$-kal alacsonyabb implantációs rátát tapasztaltak, míg az ötödik napi biopszián átesett blasztociszták implantációs rátája nem tért el szignifikánsan a kontrollcsoportéhoz képest. FISH alkalmazásával végzett preimplantációs genetikai szû́rések (PGS) eredménytelenségével kapcsolatban már korábban is felmerült, hogy a preembriók mozaicizmusa mellett esetleg az alkalmazott biopsziás technika is ronthatja az esélyeket [30]. Az implantáció szempontjából a preembriók életképességén kívül sok egyéb tényezőt is figyelembe kell venni, így Scott és mtsai 2013-ban publikált eredményeit [29] is ennek megfelelően kell értékelni. Másrészt a trophectoderma-biopszia technikai kivitelezése nehezebben illeszthető be a labor napi rutintevékenységébe. A harmadik napon kiváló értékelést kapott preembrióknak is csak egy része jut el a blasztociszta stádiumba. Ráadásul az ötödik napon ezek is a blasztuláció különböző szakaszában tartanak, így a mintavétel optimális időpontja is eltérő lehet. Saját tapasztalataink szerint a trophectoderm sejtek sem minden esetben bújnak ki a zona pellucidán korábban ejtett nyíláson keresztül, ami megnehezíti a mintavételt.

A jelen publikációnkban bemutatott sikeres PGD-ciklusunkkal együtt eddig 12 páciensnél 17 alkalommal nyertünk petesejtet és 13 esetben ültettük be a felengedett blasztocisztákat. Az embriótranszfert követően hét esetben jött létre terhesség. Saját eredményeink így megerősítik a Chang és mtsai [11] által közölt eredményeket.

\section{Következtetés}

Trophectoderma-biopszia és vitrifikáció kombinációja hatékony módszer monogénes betegségek preimplantációs genetikai diagnózisa esetén. A nemzetközi szakirodalomban publikált terhességi eredményeket viszont csak nagyobb beteganyagon végzett statisztikai elemzések után tekinthetjük mérvadónak.

Anyagi támogatás: A közlemény megírása és a kapcsolódó kutatómunka anyagi támogatásban nem részesült.

Szerzôi munkamegosztás: M. Sz.: IVF-ET kezelés elvégzése, a vizsgálat előkészítése, az esetismertetésben bemutatott trophectoderma-biopszia/vitrifikáció elvégzése, a kéziratban hivatkozott trophectoderma-biopsziák/ vitrifikációk elvégzése, kézirat megírása. V. T.: Molekuláris genetikai vizsgálat beállítása, vizsgálat elvégzése, kézirat megírása, a kéziratban hivatkozott vizsgálatok beállítása és elvégzése. K. P.: IVF-ET kezelés elvégzése, a kézirat megírása és ellenőrzése. K. M.: A kézirat megírása és ellenőrzése. R. K., B. É.: IVF-ET kezelés elvégzése, a kéziratban hivatkozott trophectoderma-biopsziák/vitrifikációk elvégzése. Sz. B.: IVF-ET kezelés elvégzése, vitrifikált blasztociszták felengedése, a kéziratban hivatkozott trophectoderma-biopsziák/vitrifikációk elvégzése. K. G. S., Sz. Z.: A kézirat ellenőrzése.

Érdekeltségek: A szerzőknek nincsenek érdekeltségeik. 


\section{Irodalom}

[1] Handyside, A. H., Kontogianni, E. H., Hardy, K., et al.: Pregnancies from biopsied human preimplantation embryos sexed by Yspecific DNA amplification. Nature, 1990, 344(6268), 768-770.

[2] Ogilvie, C. M., Braude, P. R., Scriven, P. N.: Preimplantation genetic diagnosis - an overview. J. Histochem. Cytochem., 2005, 53(3), 255-260.

[3] Harper, J. C., Geraedts, J., Borry, P., et al.: Current issues in medically assisted reproduction and genetics in Europe: research, clinical practice, ethics, legal issues and policy. Eur. J. Hum. Genet., 2013, 21(Suppl. 2), S1-S21.

[4] Sermon, K.: Current concepts in preimplantation genetic diagnosis (PGD): a molecular biologist's view. Hum. Reprod. Update, 2002, 8(1), 11-20.

[5] Thornhill, A. R., Snow, K.: Molecular dignostics in preimplantation genetic diagnosis. J. Mol. Diagn., 2002, 4(1), 11-29.

[6] Handyside, A. H.: 24-chromosome copy number analysis: a comparison of available technologies. Fertil. Steril., 2013, 100(3), 595-602.

[7] De Vos, A., Van Steirteghem, A.: Aspects of biopsy procedures prior to preimplantation genetic diagnosis. Prenat. Diagn., 2001, 21(9), 767-780.

[8] Dumoulin, J. C., Bras, M., Coonen, E., et al.: Effect of $\mathrm{Ca}^{2+}$ / $\mathrm{Mg}^{2+}$-free medium on the biopsy procedure for preimplantation genetic diagnosis and further development of human embryos. Hum. Reprod., 1998, 13(10), 2880-2883.

[9] Verlinsky, ., Ginsberg, N., Lifchez, A., et al.: Analysis of the first polar body: preconception genetic diagnosis. Hum. Reprod., $1990,5(7), 826-829$.

[10] Dokras, A., Sargent, I. L., Ross, C., et al.: Trophectoderm biopsy in human blastocysts. Hum. Reprod., 1990, 5(7), 821-825.

[11] Chang, L. J., Huang, C. C., Tsai, . $\Upsilon$., et al.: Blastocyst biopsy and vitrification are effective for preimplantation genetic diagnosis of monogenic diseases. Hum. Reprod., 2013, 28(5), 14351444.

[12] Verlinsky, Y., Pergament, E., Strom, C.: The preimplantation genetic diagnosis of genetic diseases. J. In Vitro Fert. Embryo Transf., 1990, 7(1), 1-5.

[13] Gianaroli, L., Magli, M. C., Ferraretti, A. P., et al.: Preimplantation diagnosis for aneuploidies in patients undergoing in vitro fertilization with a poor prognosis: identification of the categories for which it should be proposed. Fertil. Steril., 1999, 72(5), 837-844

[14] Munné, S., Magli, C., Cohen, J., et al.: Positive outcome after preimplantation diagnosis of aneuploidy in human embryos. Hum. Reprod., 1999, 14(9), 2191-2199.

[15] ESHRE PGD Consortium Steering Committee: ESHRE Preimplantation Genetic Diagnosis (PGD) Consortium: data collection II (May 2000). Hum. Reprod., 2000, 15(12), 2673-2683.

[16] International Working Group on Preimplantation Genetics: Tenth anniversary of preimplantation genetic diagnosis. J. Assist. Reprod. Genet., 2001, 18(2), 64-70.
[17] Findlay, I.: Pre-implantation genetic diagnosis. Br. Med. Bull., 2000, 56(3), 672-690.

[18] Trounson, A., Mohr, L.: Human pregnancy following cryopreservation, thawing and transfer of an eight-cell embryo. Nature, 1983, 305(5936), 707-709.

[19] Downing, B. G., Mohr, L. R., Trounson, A. O., et al.: Birth after transfer of cryopreserved embryos. Med. J. Aust., 1985, 142(7), 409-411.

[20] Rall, W. F., Fahy, G. M.: Ice free cryopreservation of mouse embryos at $-196{ }^{\circ} \mathrm{C}$ by vitrification. Nature, 1985, 313(6003), $573-575$.

[21] Vajta, G., Holm, P., Kuwayama, M., et al.: Open pulled straw (OPS) vitrification: a new way to reduce cryoinjuries of bovine ova and embryos. Mol. Reprod. Dev., 1998, 51(1), 53-58.

[22] Kuwayama, M.: Highly efficient vitrification for cryopreservation of human oocytes and embryos: the Cryotop method. Theriogenology, 2007, 67(1), 73-80.

[23] Desai, N., Blackmon, H., Szeptycki, J., et al.: Cryoloop vitrification of human day 3 cleavage-stage embryos: post-vitrification development, pregnancy outcomes and live births. Reprod. Biomed. Online, 2007, 14(2), 208-213.

[24] Kasai, M., Mukaida, T.: Cryopreservation of animal and human embryos by vitrification. Reprod. Biomed. Online, 2004, 9(2), 164-170.

[25] Steblik, E., Steblik, J., Katayama, K. P., et al.: Vitrification demonstrates significant improvement versus slow freezing of human blastocysts. Reprod. Biomed. Online, 2005, 11(1), 53-57.

[26] Balaban, B., Urman, B., Ata, B., et al.: A randomized controlled study of human day 3 embryo cryopreservation by slow freezing or vitrification: vitrification is associated with higher survival, metabolism and blastocyst formation. Hum. Reprod., 2008, 23(9), 1976-1982.

[27] Sifer, C.: Contribution of embryo vitrification procedure to ART efficiency. Gynecol. Obstet. Fertil., 2014, 42(10), 721-724. [Article in French]

[28] Levi Setti, P. E., Porcu, E., Patrizio, P., et al.: Human oocyte cryopreservation with slow freezing versus vitrification. Results from the National Italian Registry data, 2007-2011. Fertil. Steril., 2014, 102(1), 90-95.e2

[29] Scott, R. T. Jr., Upham, K. M., Forman, E. J., et al.: Cleavagestage biopsy significantly impairs human embryonic implantation potential while blastocyst biopsy does not: a randomized and paired clinical trial. Fertil. Steril., 2013, 100(3), 624-630.

[30] Mastenbroek, S., Twisk, M., van der Veen, F., et al.: Preimplantation genetic screening: a systematic review and meta-analysis of RCTs. Hum. Reprod. Update, 2011, 17(4), 454-466.

(Mátyás Szabolcs dr., Budapest, Istenhegyi út 54/A, 1125 e-mail: szmatyas@hotmail.com) 